\title{
Stem Cell Isolation
}

National Cancer Institute

\section{Source}

National Cancer Institute. Stem Cell Isolation. NCI Thesaurus. Code C113053.

Recovery and purification of stem cells from human sources, including umbilical cord blood. 